\title{
MFC-Based Biosensors Known as an Integrated and Self-Powered System
}

\author{
Marjan Fallaha and Mostafa Rahimnejada* \\ Biofuel \& Renewable Energy Research Center, Department of Chemical Engineering, Iran
}

*Corresponding author: Mostafa Rahimnejada, Biofuel and Renewable Energy Research Center, Department of Chemical

Engineering, Iran

\begin{tabular}{|c|c|}
\hline ARTICLE INFO & ABSTRACT \\
\hline Received: 幽 February 04, 2019 & Citation: Mostafa Rahimnejada. MFC-Based Biosensors Known as an Integrated and \\
\hline Published: 蔧 February 11, 2019 & Self-Powered System. Biomed J Sci \& Tech Res 14(2)-2019. BJSTR. MS.ID.002538. \\
\hline
\end{tabular}

\section{Mini Review}

Main sources of energy are classified into three significant batches such as fossil fuels, nuclear sources and renewable ones [1], in which fossil fuels and nuclear ones known as non-renewable sources of energy involve a massive quota energy uses all around the world [2]. Carbon dioxide emission, global warming and atmospheric contamination are the main drastic disadvantages of non-renewable energy consumption by the people, which negatively influence whole the environment [3]. As a piece persuasive solution to the energy crisis, tremendous efforts have been done by huge number of scientists by turning the eyes into consumption of renewable sources of energy rather than non-renewable ones [4]. Microbial Fuel Cells (MFCs) as the main type of Fuel Cells (FCs) can apply active microorganisms as biocatalysts instead of those metal ones in an anaerobic anode part for bioelectricity production [5,6]. By an overall view, MFCs consist of a cathode and an anode compartments separated by a Proton Exchange Membrane (PEM) Figure 1, in which electrons as protons in anode compartment are produced by oxidizing of organic matters with the help of biocatalysts [7].

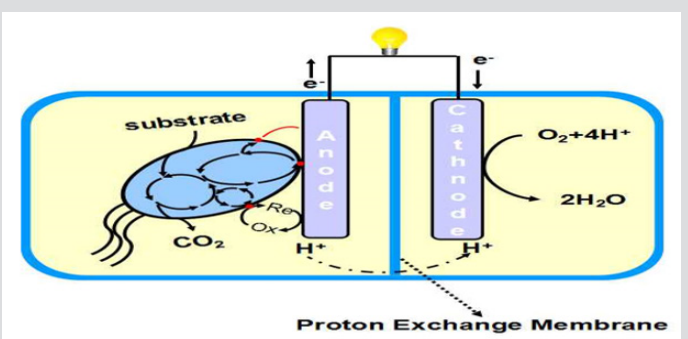

Figure 1: An MFC system consisted of anode and cathode compartments [11].
Generated protons directed to the cathode part through PEM and the electrons conduct through the external circuit. Along with Oxygen Reduction Reaction (ORR) in cathode part, protons and electrons reacted there which resulted in water molecule production. Electricity generation, biohydrogen production and as an energy production technology in wastewater treatments, are the most significant applications of MFCs nowadays [8].

Many other investigations aim towards applying MFCs providing power for some electronic sensors and biosensors, the main topic at this mini review [9]. Sensors are introduced as an electronic device able to detect any properties and quantifying their changes. The biological response get by the sensor will be converted to an electrical and measurable response by using a transducer. In selfpowered MFC-based sensors and biosensors any transducer is not needed, since the current output is a measurable response by itself [10]. Toxicity detection in any water sample is going to be crucial matter of these years to specify vital actions providing safe water with an appropriate level of quality to be consumed by human beings. To this effect, MFCs can be defined as an appropriate and sensitive device, since any toxicants in anode compartment of MFCs would directly affect the metabolic activity of the microbes and consequently the output current of the system [12].

\section{Conclusion}

By this summary strong potential of MFCs specifically in the field of sensors and biosensors has been illustrated. MFC's current output is shown to be low compared with other electrical energy sources. However, MFCs are capable to be used as power supplies 
for any low-power electronic remote sensors such as pH sensors Also they can be identified as a self-powered biosensors to monitor COD, toxicity and BOD in water due to their high sensitivity and rapid response.

\section{References}

1. M Rahimnejad, A Adhami, S Darvari, A Zirepour, S EJAEJ Oh (2015) Microbial fuel cell as new technology for bioelectricity generation: A review. Alexandria Eng J 54(2015): 745-756.

2. M Rahimnejad, N Mokhtarian, G Najafpour, AA Ghoreyshi, WRW Dahud (2009) Effective parameters on performance of microbial fuel cell, Environmental and Computer Science IEEE2009 pp. 411-415.

3. M Rahimnejad, A Ghoreyshi, G Najafpour, H Younesi, MJIjohe Shakeri (2012) A novel microbial fuel cell stack for continuous production of clean energy. International Journal of Hydrogen Energy 37(7): 59926000 .

4. SJ Peighambardoust, S Rowshanzamir, MJIjohe Amjadi (2010) Review of the proton exchange membranes for fuel cell applications. International J Hydrogen Energy 35(17): 9349-9384.

5. M Rahimnejad, AA Ghoreyshi, G Najafpour, TJAE Jafary (2011) Power generation from organic substrate in batch and continuous flow microbial fuel cell operations. Applied Energy 88(11): 3999-4004.

ISSN: 2574-1241

DOI: 10.26717.BJSTR.2019.14.002538

Mostafa Rahimnejada. Biomed J Sci \& Tech Res (c) This work is licensed under Creative

Submission Link: https://biomedres.us/submit-manuscript.php
6. A Tardast, M Rahimnejad, G Najafpour, AA Ghoreyshi, HJ Zare (2012) Fabrication and operation of a novel membrane-less microbial fuel cell as a bioelectricity generator. IJEE 3: 1-5.

7. M Nader, R Wan, M Rahimnejad, G Najafpour (2012) Bioelectricity generation in biological fuel cell with and without mediators 18(4): 559-567.

8. F Ivars-Barceló, A Zuliani, M Fallah, M Mashkour, M Rahimnejad, et al. (2018) Novel Applications of Microbial Fuel Cells in Sensors and Biosensors. Appl Sci 8(7): 1184.

9. Y Yi, B Xie, T Zhao, Z Li, D Stom, et al. (2019) Effect of external resistance on the sensitivity of microbial fuel cell biosensor for detection of different types of pollutants. Bio electrochemistry 125: 71-78.

10. BE Logan (2009) Exo electrogenic bacteria that power microbial fuel cells 7(5): 375-381.

11. Logan BE1, Hamelers B, Rozendal R, Schröder U, Keller J, et al, (2006) Microbial fuel cells: methodology and technology. Environ Sci Technol 40(17): 5181-5192.

12. NE Stein, HM Hamelers, G van Straten, KJ Keesman (2012) On-line detection of toxic components using a microbial fuel cell-based biosensor. J Proc Con 22(9): 1755-1761.

$\begin{array}{ll}\text { BIOMEDICAL } & \text { Assets of Publishing with us } \\ \text { RESEARCHES } & \text { - Global archiving of articles } \\ \text { - Immediate, unrestricted online access }\end{array}$

